\title{
METHODICAL SUPPORT OF ASSESSMENT OF THE DEVELOPMENT OF ECONOMIC SECURITY OF THE REGION
}

\author{
Ganna lefimova ${ }^{1}$, Andrey Labartkava $^{2}$, Oleksiy Pashchenko ${ }^{3}$
}

\begin{abstract}
The subject of research is actual problems of diagnostics of threats and risks of regional development, factors of economic safety, methodological support of its estimation. The aim is to formulate a methodological framework for assessing the economic security of the regions development. The formation of the research methodology is carried out on the basis of theoretical and methodological platform for the development of rating method for assessing the economic security of the region. The use of the matrix method for describing the initial state of the system has been justified; the method of normalized values has been used for bringing various indices. Factors influencing the level of investment activity and economic security of the region have been identified. All factors that change the level of economic security are divided into four groups depending on the macroeconomic indicators, the level of which they take into account. It is proposed to divide them into two groups - direct action factors that increase the level of safety and reverse action factors that reduce it. Indicators characterizing the economic development of the region have been grouped by factors of economic security. For each group, the significance of the impact of indicators of individual groups for evaluation of the economic security of the region development has been determined. To estimate the economic security of the regions' development, it was proposed to use an integral indicator based on the state of general economic development, investment activity in the region and demographic indicators of economic development. Depending on the influence of individual factors, the rank of each region is determined first for each group of factors, and then the integral. According to the results of the assessment of the economic security of regions' development by individual groups of factors and the calculated integral indicator, the place of each region has been determined by the level of economic security. The result of the study is classification of the regions according to certain criteria on the basis of the integral index of economic security of the regions' development, which will allow not only to compare the level of economic security, but also to formulate a nationally balanced regional development strategy and identify priority investment areas.
\end{abstract}

Key words: economic security, economic development, region, risk, threat.

JEL Classification: 010, R13, G32

\section{Introduction}

The economic security of the socio-economic system can be characterized as a state of stability, when this system can do its activity by saving the balance and the general direction of the development in the conditions of the environment, which is transforming dynamically, including in the conditions of the active and increased influence of the destabilizing factors (Filipova, Voloshchuk, Cherkasova, 2015).

\footnotetext{
Corresponding author:

${ }^{1}$ Admiral Makarov National University of Shipbuilding, Ukraine.

E-mail: hanna.yefimova@nuos.edu.ua

ORCID: https://orcid.org/0000-0001-5271-2913

${ }^{2}$ Admiral Makarov National University of Shipbuilding, Ukraine.

E-mail: andreynuk@gmail.com

ORCID: https://orcid.org/0000-0003-0026-0817

${ }^{3}$ Admiral Makarov National University of Shipbuilding, Ukraine.

E-mail: oleksiy.pashchenko@nuos.edu.ua

ORCID: https://orcid.org/0000-0001-9513-8632
}

The most important value in the complex of the ways to form the system of the economic security is to develop the methodology of the analysis and the diagnostics of the threats and the risks, which destabilize the system activity (Dykan, 2017; Iefimova, Marushchak, 2017; Van Thanh Do, 2019).

The modern conditions of the reforms of decentralization in the post-Soviet countries stipulate the necessity of the theoretical and practical 
developments for support of the development of economic security of the regions. The unfavorable investment climate comparing with the countries of Central and Eastern Europe and low volumes of the foreign investments shows the low level of the economic security of the countries in whole. Inside the countries the conditions for the activity of the agents of the economic management have the essential differences. It is known the cases when the enterprises go out of business in one region and at the same time they extend activity in others. The serious confirmation of the nonuniformity of the investment climate of the regions is the character of the territorial division of the investments into the national economics (Dykan, 2017).

The problem of development of the economic security assessment in whole and in the regional aspect has been considered many times in the economic literature. Today the scientists and the experts consider the problems very often. They are connected with the peculiarities of the economic development risks appearance (Hrinchenko, 2017; Varnalii, 2018; Van Thanh Do, 2019; Wimbush, Tsereteli, 2008; Yapatake, Thales, Shan Li Jin, 2018). In spite of it, the most points concerning the questions of the economic development management at the regional level are too one-sided. The efficiency of the economic processes in the modern conditions of the development of national economy is connected inseparably with the assessment of the current position and the identification of the main tendencies of the business activity development. The process of the study of economic development consists of the assessment and the forecast of the enterprises activity which are the subjects of the economics and the assessment of the economic security in the separate regions like the external conditions of the enterprises functioning.

The aim of this study is to formulate the methodical support of the development of economic security of the regions.

\section{Methods of describing the initial state and reduction of indicators}

For the assessment of the economic security of the development of the regions, it is appropriate to use the rating method, which is based on the calculation of the integral index of the economic security of development of the regions. For its calculation, it is necessary to analyze the factual indices of the economic development of the regions and compare them with the standardized values which allow to compare the influence of the different factors into the generalized index of the economic security.

We suppose that $i$ is the number of regions and each of them is characterized by many $j$ factors.Then each considered region can be introduced like the point of $j$-dimensional space with the coordinates which are equal to the values of each $j$ factor.
The matrix of the researches is formed at the initial stage of the analysis of the regional investment risk. It consists of the complete characteristics of the analyzed regions:

$$
X=\left|\begin{array}{cccc}
x_{11} & x_{12} & \ldots & x_{1 i} \\
x_{21} & x_{22} & \ldots & x_{2 i} \\
\ldots & \ldots & \ldots & \ldots \\
x_{j 1} & x_{j 2} & \ldots & x_{j i}
\end{array}\right|
$$

Where $i$ is the number of the analyzed regions; $j$ is the number of factors ;

$x_{j i}$ is the value of the factor $j$ for the region $i$.

The lines of $X$ matrix are in accordance with the analyzed regions, and the columns are in accordance with the factors, the matrix of them includes the most characterized marks of the development of regions.

Because the factors of the matrix $X$ characterize the different qualities of the analyzed objects, they are nonuniform and differ by units of the measurement. For the calculation of the index of development of the economic security of the region, it is necessary to execute the transformation of the matrix $X$ for the standardization of the factor indices.We will form the matrix $Z$ :

$$
Z=\left|\begin{array}{cccc}
z_{11} & z_{12} & \ldots & z_{1 i} \\
z_{21} & z_{22} & \ldots & z_{2 i} \\
\ldots & \ldots & \ldots & \ldots \\
z_{j 1} & z_{j 2} & \ldots & z_{j i}
\end{array}\right|
$$

The elements of the matrix $Z$ are calculated by use of the following method:

$$
z_{i j}=\frac{x_{i j}-x_{j}^{-}}{x_{j}^{+}-x_{j}^{-}}
$$

Where $\mathrm{zij}$ is the standard value of the factor $j$ for region $i$;

$x_{j}^{-}$is the minimal value of the factor $j$;

$x_{j}^{+}$is the maximum value of the factor $j$.

Then the calculation of the group indices of development of economic security of the region is executed, which are the synthetic value of many factors. They characterize the object of the analysis of this group. The calculation of these indices allows to order the elements of the set - the analyzed regions - up to the definite standard.

In accordance with each factor of the matrix $Z$ the minimal value (for the factor indices, their increase decreases the level of the economic security) or maximum value (for the factor indices, the increase of them increases this level) is calculated, which allows to calculate so called standard, i.e. the highest level of the economic security.

The errors of the real indices of the economic security of the analyzed objects from standard are calculated using this method:

$$
r_{i 0}=\sqrt{\sum_{1}^{j}\left(z_{i j}-z_{0 j}\right)^{2}}, i=\overline{1, M}
$$


The received error is the base for the calculation of the group indices of the development of economic security of the region:

$$
d_{i}=\frac{r_{i 0}}{r_{0}}
$$

Where $r_{0}=\max _{i}\left\{r_{i 0}\right\}$.

The group indices of the region development economic security have been interpreted: the value of the index $d_{i}$ is closer to 1 , than it is safer the $i$-th region.

\section{Systematization of factors and indicators of economic security of the region}

For the comparison of the level of economic security of the region the system of the factors, which effect into this level, has been formed. Such main factors should be separated out between set of the factors which stipulate the difference in the levels of development of economic security of the region:

1) the level of the general economic development of the region;

2) the level of the investment activity in the region;

3) the level of the development of the enterprise activity and the investment infrastructure;

4) the demographic characteristics of the region.

All these factors have the same direction of activity, i.e. the positive dynamics of the indices, which characterizes them should support the increase of the economic security and the decrease of the risk of the region development.

The assessment of the economic security has been executed on the base of the indices which characterize the achieved level of economic development of the region. This assessment can consider the objective because the achieved parameters have been considered so that they characterize, on the one hand, the definite level of the economic development and, on the other hand, the preconditions of the further activity. Due to the stability of many regional development factors the results of the assessment of the economic security are usually not inclined to the sharp changes and the results of the executed assessment can be used at the design of the strategy of the region development or at its longterm forecast.

For the assessment of development of economic security of the regions should calculate and extend the results of the influence of the separated factors. The influence of each of them is calculated by line of indices, the level and the dynamics of which determine the change of the climate and the risk of the economic activity in the region.

For the characteristics of the economic security of the regions development it is proposed to calculate and study the specific analytical indices, which are grouped in accordance with the factors of the economic security.
The level of the general economic development of the region is calculated on the base of such indices:

- the gross additional value - it shows the final result of the activity of the economic management agents and it is the measure of the economic activity efficiency;

- the volume of export-import (the balance) characterizes the result of the foreign economic activity of the enterprises;

- the index of the consumption prices is the index of change of the general level of price and tariff it shows the level of inflation, which is one of the main factors for the deterrence of development of the region's economy; - the obligations of the banks concerning money, which have been borrowed at the accounts of the natural persons, show the change of capital which has been accumulated in the bank field.

The level of the investment activity in the region has been valued on the base of the following analytical indices:

- the total sum of the investments characterizes the development and the regional structure of the investment activity in the country and it is the main index which shows the level of the investment activity and the stage of the economic security;

- the rate of the increase of investments during last year characterizes the dynamics of the investment activity in the regions and shows the change of risk of the investment from the investors point of view;

- the implementation of the new main ways shows the use of the investments in the fixed capital like the result of the investment process;

- the direct foreign investments in the regions characterize the relation of the foreign investors to the investment climate in the regions and their assessment of the economic risk.

The level of the development of the enterprise activity and the investment infrastructure is characterized by the following main indices:

- the number of the created enterprises shows the enterprise activity in the region, which is the result and, at the same time, the precondition of its development; - the number of small enterprises characterizes the level of the development of the small business, like one of the main parameters of the economic increase;

- the structure of the credit debt is one of the main indices of the enterprises financial state which shows the level of the accounts risk into their activity;

- the requirements of the banks concerning the credits, which have been given into the economics, characterize the volume of the investments, received in the real sector of the economics in the bank field.

The demographical characteristics of the region are calculated on the basis of the following indices:

- the quantity of the population;

- the quantity of the worked population;

- the average level of the salary;

- the migration increase of the population. 
These four indices in whole characterize the level of support by the human resources of the regions and their cost, which is one of the determinative indices of the result of the region economics and the source of its development.

But not all factors have the same influence into risk of the investment activity in the region. So, it is proposed to establish such value of the weightiness of the influence of the separate groups of the indices for the assessment of development of economic security of the region, it is proposed to use the following value of the specific elements:

- the level of the general economic development - 35\%; - the level of the investment activity in the regions $-25 \%$;

- the level of the development of the enterprise activity and the investment infrastructure - 25\%;

- the demographical characteristics of the region $-15 \%$.

\section{Method of assessing the economic security of the region}

The calculation of the integral indice of development of economic security of the regions has been executed by use of this formula:

$$
D_{i}=d_{i 1} \times v_{1}+d_{i 2} \times v_{2}+d_{i 3} \times v_{3}+d_{i 4} \times v_{4}
$$

where $d_{1}, d_{2}, d_{3}, d_{4}$ are the indices of the economic security development of $i$-th region in accordance with four factors, which have been determined by assessment of the appropriate groups of indices;

$v_{1}, v_{2}, v_{3}, v_{4}$ are the weight of the appropriate element in the general assessment of the region, it is expressed like decimal fraction.

In accordance with the results of the assessment of the integral indices of the economic security by use of the specific factors and the calculated integral indice of the economic security of the regions, the place of each region in accordance with the level of security of development has been determined. It is proposed to define three groups of the regions:

- the first group includes the regions with high level of the economic security;

- the second group contains the regions with the average level of the economic security;

- the third group consists of the regions with low level of the economic security.

The criterion for the assessment is the integral indice of the economic security of the development, which generalizes the rate of the region in accordance with each group of factors:

- for the regions with low level of the economic security the integral indice is $D_{i} \leq 0.65$;

- for the regions with average level of security the integral indice is $0.65>D_{i} \geq 0.8$;

- for the regions with high level of security the integral indice is $0.8>D_{i} \geq 1$.
In accordance with the integral indice of the economic security of the region development the absolute level of the economic security has been valued up to the standard. The comparative security of development should be determined with the aim to form the national policy of the economic development and the risk of the investment into the economics of the different regions. On the base of such assessment the most favorable regions should be marked for the investment with minimal risk. The perspectives of the regions development are characterized by the socioeconomic potential, the technical level of the industry and the level of urbanization of the population and the provision by the qualified staff. The regions are valued by the availability of the consumer goods and the factors of production.

\section{Conclusions}

For the assessment of development of economic security of the regions, the integral index has been used, which is based on the calculation of the general economic development state, the investment activity in the region and the demographic indices of the economic development. The rate of each region is determined in accordance with the influence of the specific factors for each group of factors and the integral.

The study identified factors that affect the level of economic security and the degree of risk of economic activity in the region. All the factors that change the economic security in a particular region have been divided into four groups depending on the macroeconomic indicators they take into account. Of course, not all factors have the same course of action, which was taken into account when assessing the level of economic security in the region. Therefore, it is proposed to divide them into two groups: direct action factors that increase the level of safety, and reverse action factors that reduce it. It is also determined that not all factors have the same degree of impact on the risks and threats that exist in the regional economy. The significance of each group of factors was taken into account, taking into account the impact it has on the level of economic security of the region.

In accordance with the results of the assessment of the indices of the economic security development of the regions on the specific groups of factors and the calculated integral indice, the place of each region is determined in accordance with the level of the economic security. On the base of the integral indice of development of economic security of the regions, the typification of the regions is executed in accordance with the determined criterion, which allows to compare the levels of the security, to form national balanced strategy of the regions development and to determine the priority directions of the investment. 


\section{References:}

Hrinchenko, Ye. (2017). Tekhnolohiia dovhostrokovoho prohnozuvannia pry upravlinni rozvytkom rehionalnykh makroekonomichnykh system na osnovi imitatsiinoi modeli [Technology of the long-term forecast at the management of the development of the regional macroeconomic systems on the base of the simulation model]. Visnyk Natsionalnogo universytetu tsivilnogo zahystu Ukrainy (Seriia: Dergavne upravlinnia), vol. 6, pp. 271-280. (in Ukrainian)

Varnalii, Z. (2018). Regional aspect of investment security of Ukraine. Economics and Region, vol. 4(71), pp. 5-30. Dykan, V. (2017). Mekhanizm zabezpechennia ekonomichnoi bezpeky rehionu: sutnist, skladovi, napriamy dii [Mechanism of the region economic security support: the core, the components, the directions of the activity]. Visnyk ekonomiky transportu i promyslovosti, vol. 58, pp. 18-25. (in Ukrainian)

Filipova, S., Voloshchuk, L., \& Cherkasova, S. (2015). Ekonomichna bezpeka pidpryiemstv realnoho sektoru ekonomiky v umovakh vartisno-oriientovanoho upravlinnia [Economic security of the enterprises in the real sector of economics in the conditions of the cost-oriented management]: the monography, under main edition of S. Philipova. Edit by M. Bondarenko. (in Ukrainian)

Iefimova, H., \& Marushchak, S. (2017). Modeling of the enterprise economic security. Mechanisms of interaction between competitiveness and innovation in modern international economic relations: collective monograph. ISMA University. "Landmark" SIA. Vol. 4, pp. 36-45.

Mamoon, D. (2012). Economic security, well functioning courts and a good government. International Journal of Social Economics, vol. 39.8, pp. 587-611.

Van Thanh Do (2019). Macro-econometric model for medium-term socio-economic development planning in Vietnam. Part 1: Structure of the model. Economy of region, vol. 1.1, pp. 121-136.

Wimbush, S. E., \& Tsereteli, M. (2008). Economic security and national security: Connected in Georgia. Asia-Caucasus Analyst, Bi-Weekly Briefing, vol. 10.2, p. 23.

Yapatake, K., Thales, P., \& Shan Li Jin (2018). Economic Security and the Political Governance Crisis in Central African Republic. African Development Review, vol. 30.4, pp. 462-477. 